\title{
Processo oxidativo em doadores de sangue portadores de Hemoglobina S e mutantes no gene $\mathrm{HFE}$

\author{
Oxidative process in blood donors with hemoglobin S and HFE gene mutations
}

Ligia Marcia S. V. Baracioli

Orientador: Claudia R. Bonini-Domingos

\section{Resumo}

A Hb S apresenta efeito sobre as células sanguíneas, desencadeando processos oxidativos com geração de radicais livres. Efeito semelhante observa-se no acúmulo de ferro, em decorrência da hemocromatose hereditária. Os defeitos de metabolismo do ferro, em especial aqueles oriundos dos polimorfismos no gene HFE, levam ao acúmulo de ferro tecidual, com potencial capacidade oxidante e peroxidação lipídica. Fundamentados no possível efeito tóxico decorrente da mutação no gene da globina $\aleph^{\mathrm{S}}(\mathrm{Hb} \mathrm{S})$ e do acúmulo de ferro tecidual, relatados na literatura, objetivou-se avaliar a influência dos polimorfismos do gene $H F E$ na peroxidação lipídica dos portadores dessa alteração de hemoglobina e sua relação com o aumento da destruição eritrocitária e geração de estresse oxidativo. Foram analisadas 16 mil amostras de doadores de sangue e encontrou-se uma frequência de Hb AS de 1,69\% na região noroeste do estado de São Paulo. Destes, 43 apresentaram concomitância na herança da Hb S e de pelo menos um dos dois polimorfismos no gene HFE testados. A frequência dos polimorfismos C282Y e H63D, no gene HFE, no grupo de doadores com $\mathrm{Hb} \mathrm{AS}$, está de acordo com o esperado para a região de estudo. Entre os doadores de sangue com $\mathrm{Hb}$ AS e com a herança concomitante dos polimorfismos no gene HFE, os níveis de MDA estavam elevados, indicando a influência de ambas as afecções genéticas, no aumento dos níveis de peroxidação lipídica. Entretanto, os níveis médios da TEAC, indicativo da capacidade oxidante, apresentaram-se dentro dos valores normais. Esses resultados indicam que, apesar de haver um aumento da peroxidação lipídica neste grupo, este não é acompanhado pelo aumento da capacidade antioxidante, podendo gerar estresse oxidativo.

Palavras-chave: Hemoglobinopatias; hemoglobina S; HFE; capacidade antioxidante; estresse oxidativo

\begin{abstract}
Hemoglobin S has an effect on blood cells, triggering oxidative processes with the formation of free radicals. A similar effect is observed with iron overload as a result of hereditary hemochromatosis. Defects of the iron metabolism, in particular those related to HFE gene polymorphisms, lead to tissue iron overload with potential oxidant capacity and lipid peroxidation. Based on the possible toxic effect of mutations of the $\aleph^{S}$ globin $(\mathrm{Hb} \mathrm{S})$ gene and the accumulation of iron in the tissue, this study aimed at evaluating the influence of HFE gene polymorphisms on the lipid peroxidation in hemoglobin $\mathrm{S}$ carriers and the relationship with increased red blood cell destruction and oxidative stress. A total of 16,000 blood samples from donors were evaluated and a frequency of $1.69 \%$ was found for Hb AS in the region of northwest São Paulo state. Forty-three presented concomitant inheritance of $\mathrm{Hb} \mathrm{S}$ and one of the two HFE gene polymorphisms tested. The frequency of C282Y and H63D polymorphisms in the Hb AS blood donor group is in agreement with population studies from the region. We also verified that the MDA levels were elevated in the group of blood donors with $\mathrm{Hb}$ AS and concomitant HFE gene polymorphisms, demonstrating the influence of both genetic disorders on the levels of lipid peroxidation. However, the average levels of TEAC, indicative of the oxidative capacity, were within the normal range. These results show that, in spite of an augment in lipid peroxidation, an increase in the antioxidant capacity, leading to oxidative stress, is not observed
\end{abstract}

Key words: Hemoglobinopathies; sickle cell disease;HFE; hemochromatosis; antioxidant capacity; stress oxidative.

Avaliação: A RBHH publica os resumos e abstracts de teses da área apresentados em entidades que tenham programas de pós-graduação reconhecidos pelo MEC/Capes e considera a obtenção do título suficiente para sua publicação na forma como se propõe a seção.

Suporte Financeiro: CNPq

Recebido: $18 / 3 / 2009$

Aceito: 20/03/2009

Resumo de dissertação para obtenção do título de Doutor em Genética, apresentada ao Instituto de Biociências, Letras e Ciências Exatas, Programa de Pós-Graduação em Genética. Campus de São José do Rio Preto - Unesp.

Correspondência: Ligia Marcia da Silveira Viana Baracioli

LHGDH-Unesp

Rua Cristóvão Colombo, 2265 - Jardim Nazareth

15054-000 - São José do Rio Preto-SP - Brasil

E-mail:libaracioli@yahoo.com.br 